\title{
Howard Becker, Drug Use and the Sociology of Deviance
}

\author{
Erich Goode* \\ Stony Brook University, Stony Brook, New York, USA
}

*Corresponding author: Erich Goode, Stony Brook University, Stony Brook, New York, USA, E-mail: egoode2001@aol.com

Received date: February 12, 2018; Accepted date: March 29, 2018; Published date: March 31, 2018

Citation: Goode E (2018) Howard Becker, Drug Use, and the Sociology of Deviance. J Drug Abuse Vol.4 No.1:8

\section{Abstract}

Outsiders, a sandwich book comprised of two previouslypublished articles on marijuana use and two on dance musicians, a two-chapter introduction, and a three-chapter conclusion (and, in the 1973 edition, the author's reappraisal of labeling theory), has been, by far, Howard S. Becker's most-read and most-cited work. It was remarkable and influential in several ways, including the fact that the author was a participant in the behavior he described and analyzed. But in his reflections on his own work, Becker expressed unease about being identified by this book, arguing that his writings in other areas are more emblematic of his contributions to sociology. Indeed, Becker even argues that, conceptually, the book wasn't even about deviance as such, but occupations and the professions. The fact remains, authors do not render the most authoritative judgment about their work-their readers and commentators do.

Keywords: Howard becker; Marijuana; Deviant behavior

\section{Introduction}

In sociology, Howard S. Becker is credited with bringing interactionism and constructionism into the study of drug use. What's important about marijuana, he argued, is how users define the substance, to themselves and to the initiate, and how lawmakers, the media, and the public at large socially and culturally construct its reality. From a constructionist point of view, Becker conceptualized marijuana use as a form of deviant behavior. What makes marijuana use a form of deviance? Wherein resides its deviant-ness? In his now-classic volume, Outsiders [1,2], Becker examined the process of rules and their enforcement and the enterprise of moral entrepreneurs, in which the rules or norms prohibiting cannabis consumption were created and implemented-no rule creation and no enforcement, no deviance.

\section{Becker's Contribution}

Howard Becker's Outsiders was different from anything that came before it; its position represented a radical departure from the field's dominant etiological and pathology orientation. Becker humanized and empathized and identified with his subjects- his "deviants": He was a marijuana smoker and a jazz musician himself; in the early sixties, very few deviance sociologists possessed the very identities they investigated. Becker set aside pathology and etiology-the "Why do they do it?" and the "How can we get them to stop?" questions and advanced an entirely different line of inquiry: How is unconventionality defined and sanctioned by the society, how does the deviator accomplish its enactment, and with what consequences?

Outsiders reconceptualised the sociology of deviance; in fact, it virtually created a field of study. And it was an enormous success; the book has been reprinted more than 20 times. Of the nearly 40,000 citations to Howard Becker's work in Harzing's Publish or Perish, almost 15,000 are to Outsiders alone, and a number of the others are to the articles that the author incorporated as chapters in the volume. Among its appeals, the approach of the book blended the notion of cultural relativity with a burgeoning sixties taste for something deliciously unconventional. And it appealed to the growing tendency on the part of young instructors of sociology who smoked marijuana and hence, became fascinated by the book.

\section{Was Outsiders About Deviance?}

There's a "but," however: In a 2002 interview with Ken Plummer, Becker says: "A lot of people think of my early work as mainly about deviance, but it's not. I never really did work on deviance as such." With respect to Outsiders and The Other Side, he said, "that was my involvement with deviance" [3]. Apparently, after having completed two books on deviance, his connection with the field was terminated. But in addition, according to Becker, the "it" wasn't even deviance in the first place.

His statement to Plummer makes three points, the first two of which seem contradictory: One, Becker says, it is true, I studied deviance, briefly in the past, but it happened by accident, and now I don't; two, the research on deviance that I conducted in the past wasn't even about deviance- it was focused on something altogether different, that is, the professions; and three, if we add up the time, effort, energy, and commitment that I devoted to the deviance enterprise, that is substantially outweighed by all my other research and intellectual endeavors. Let's examine these points more closely.

Becker describes the construction of Outsiders as following along an ad hoc, fortuitous, serendipitous process. In the early fifties, he scribbled 90 pages of notes on deviance. In the 
meantime, during the 1950s, he had also published two articles on being a jazz musician [4,5] and two on marijuana use [6,7]. A decade later, he pulled these scribbled notes on deviance out of his files and thought, "Hey, this isn't bad," and showed them to a friend and fellow researcher on a previous project. "You ought to publish this. You ought to make a book out of this, this is pretty interesting" [3]. So he sandwiched his marijuana and musician articles in between parts of the rediscovered essay on deviance, conceptually retrofitting the articles to a more "deviance" orientation, and: Voila! A book! One of the manuscript's reviewers, Kai Erikson, told him there was a "certain lack of coherence in this volume," which, Becker says, "was absolutely right" [8]. The fact is, there were no laws against being a jazz musician, as there were, at that time, against marijuana possession and sale; moreover, it's difficult to locate the "rule enforcers" with respect to playing music. Unconventional, yes; deviant-arguably not!

\section{Is Deviance an Analytic Concept?}

It's important to realize that Becker did not consider deviance an analytic category. Ernest Burgess, one of his instructors at Chicago, told him that his work on jazz musicians really belonged in the field of occupations and the professions [9]. One of the marijuana articles that became a chapter in Outsiders, Becker argued, was really about "the way social interaction affected the interpretation of individual experiences" [3]. which he later stressed in his books on students in medical school and students in college, while the other was on social logistics, overcoming or sidestepping conventional society's social control of the use of the drug to be able to buy it and use it. In the first three of these articles that became the chapters in Outsiders-one published in 1951 and two in 1953, the actual word, "deviant," appears only twice; in "Marihuana Use and Social Control," published in 1955, the word appears five times. In contrast, in the four chapters in Outsiders derived from those articles, "deviant" and "deviance" appear 24 times (and, of course, in the book's title as well). Originally, Becker did not consider the very articles that eventually constituted the core of Outsiders- the meat of the sandwich- as being "about" deviance; later, he repositioned the slant of those articles to fit the template. Ten years after the initial publication of Outsiders, Becker wrote and tacked on "Labelling Theory Revisited," the afterword or Chapter 10 for the reissue of Outsiders [2], gluing the articles more firmly to the field of deviance. For him, "deviance" is conceptually and theoretically too vague, amorphous, and omnibus to be of much use to most of what he investigated. His early works on becoming a medical student weigh much more heavily in his self-identity as a sociologist. To him, these projects are what defined his initial research, not Outsiders. They supported him, they engaged his time and effort and energy, they were full-time commitments, they entailed conducting collaborative research, and they focused on careers, professions, and socialization and cultures. But these books didn't get the same attention as Outsiders did. To Howie himself, they defined who Howard S. Becker was and what he was doing at an early stage of his career-Outsiders did not. To the outside world, it was the reverse: Outsiders received the recognition and the applauseand the citations. If that was a paradox, Becker replied with another: I am not and never was a deviance researcher. At the time, his occupation was conducting student socialization research; his hobby was deviance, the fun stuff that produced Outsiders.

Hence, what Becker produced as a deviance sociologist was one small pastiche book, Outsiders, published in 1963, reissued a decade later, based on four essentially repositioned articles as its central chapters, one 1964 anthology, The Other Side, which flowed from his editorship of Social Problems. Except for a few brief ancillary statements, that was that [3].

\section{Do Authors Label their own Work?}

What does all this add up to? It's this: In spite of his objections, Outsiders worked. Becker's view of deviance evoked a substantial response in his audiences. The creation of Outsiders was miraculously serendipitous and a remarkable achievement. Becker's Outsiders struck just the right note; it was a seed that landed on and took root in the fertile soil of the early sixties. The writings he considered his signature works didn't. In a way, Howie is guilty of the very sin he criticizes more traditional sociologists of essentialism. He "labels" his work as focusing on the professions, dismissing the fact that others "label" it as being on deviance.

"The author is dead," says critic Roland Barthes [10]; Becker doesn't get to say what his work is about. Academic recognition is particularly out of the hands of the author that has to do with resonance, not with how the author feels. Howard Becker did a great deal of interesting work on a lot of interesting subjects but he doesn't want to be narrowly confined to a single relatively low-prestige- field. Outsiders blew a breath of fresh air into the field (however "the" field is defined) because it offered a fresh approach that sociologists could use to investigate an array of behaviors and phenomena that, superficially, appear to be very different from one another. Howard S. Becker is forever labeled as the progenitor of the contemporary sociological approach to the study of deviance, and he will always be regarded as a deviance researcher. The fact that he doesn't agree is entirely beside the point. It's a case of mislabeling, Becker would sayignoring what he himself called the hierarchy of credibility [9]: "somebody" has to do the labeling, he tells us [10]. As it turns out, his readers did it-and it's not Howie. Ergo, as a result of the labeling process, Howard S. Becker is a sociologist of deviance.

\section{References}

1. Becker HS (1963) Outsiders: Studies in the Sociology of Deviance. New York: Free Press, pp: 179.

2. Becker HS (1973) Outsiders: Studies in the Sociology of Deviance (2/e). New York: Free Press.

3. Plummer Ken (2003) "Paradox and Change in Howard S. Becker's Work: An Interview with Howard S. Becker". Sociological Perspectives 46: 21-39.

4. Becker HS (1951) "The Professional Dance Musician and His Audience." Am J Sociol 57: 136-144. 
5. Becker HS (1953a) "Some Contingencies of the Professional Dance Musician's Career." Human Organization 12: 22-26.

6. Becker HS (1953b) "Becoming a Marihuana User." Am J Sociol 59: 235-242.

7. Becker HS (1955) "Marihuana Use and Social Control". Social Problems 3: 35-42.
8. Becker HS (1964) The Other Side: Perspectives on Deviance. New York: Free Press.

9. Debro J (1970) "Dialogue with Howard S. Becker." Issues in Criminology 5: 159-179.

10. Barthe R (1967) “The Death of the Author." Aspen, pp: 5-6. 